\title{
日本人にある数個の異型染色体について
}

\section{The Heteromorphic Chromosomes in the Japanese Race}

\section{小谷萬壽夫 Masuo KOTANI*}

\section{I 緒 言}

人類細胞遗伝学㹥その名称のみが存在して, 未げ系統をもつた生物学とはなつていない。 れは遗伝学の進步に件つて必岀な細胞学の発洤 が極めて不完全であることによるものであう て，著者はこの分野の成立を目標として，人間 の細胞学の開拓を計るために,この研究を始め たのである。そして既に数年を費して，基本的 ないくつかの点朝らかにし得たので，その中 の特に興味深い2,3の点をころに発表する次第 である。

\section{II 方 法}

染色体の研究は一応, 性細跑と体細胞のもの とを区别して，然もそれらを平行に調くて必

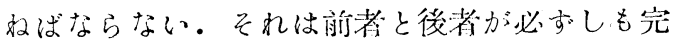
全にその数や形態に於いて一致していると限 らないからである。従つて, 吾々もこの点に留 意して, 研究を進めているが,こ了には前者, 即ち性細胞中の染色体に就いての研究の結果の 一部老說明するにとぶめたい。

さて性細胞中の染色体は, その数が個体発生 の基翰をな专ということ以外に，子孫に伝わつ てゆくものであるという点に於いて，それらの 数，形態及び伝り方に大きな重要性があるわけ で, 細胞学の開拓はますこれらの点を明らかに することから始められねばならない。そしてこ のためにはできるだけ所謂「混り」のない人種を 遙び，その中から多数の倜体をとつて，それら の性細胞中の染色体在比較研究することが最も よい方法である。この様な方法をと就ば、若し 人種間に染色体の美があつても，それによつて 研究結果の解釈がさまたげられることが少く， 一応その人種に就いては正確な結論を導くこと ができる。この意朱に於いて日本人老材料とし

\footnotetext{
* 顺天堂大学医学部解剖学教宝 客貴 1955 年 1 月 27 日受付
}

た吾々の研究には民族細胞遺伝学或は人類集団 細胞遺伀学と呼ぶべき意義があると思う。

吾々の研究に用いている技術に就いてはこ了 にふれないが，但し，材料は日本全国各地加ら 外科手術或は解剖によつて得た睪丸の一部索使 用し, spermatocyte の第一分裂の初期, 中期 を主として Feulgen 染色となすりつけ法によ つて作つたスライドに於いて観察していること を記すにとろ゙めたい。

\section{III 結果及考按}

これらの多数の材料を観察して, 吾々は先す 各個の染色体の形態を決定した。これ注第一分 裂の中期に於ける像を基とした核型であるが。 更に初期に於ける各染色体のク口モメールの pattern の決定が必要であり、これは目下進行 中であつて，既に完成したものは前記の一聯の 英交論文中に含まれているのでころには省略 与。

分裂中期の染色体像を基とした核型の決定中 筆者㟊人かの個体に於いて, 或る数個の染色 体が筫 (heteromorphic) であることを認 め, 文礼老詳しく分析して, その特性を明らか にし得たのでころにその中の三三に就いて簡 単に說明し，そ礼らの染色体異常のもつ細胞遺 伀学的意義に就いて論じてみたい。

先ずその一つは，今日までに集め得た材料中 で完全に分析を終つたものの中の 4 佔体に見出 される異型染色体奶である。この染色体は最小 のものから数えて第 2 来目に位し, 筆者が染色 体と呼ぶすの゙ある。図 1 はこの異型染色体対 を示すが,図に明らかな如くこれは大小2 個の 相同染色体より成り，両者共に centromere が 木端に非常に近く, 従つて, 短い棒状型をなし ている。分裂初期では図 2 に示すが如き形態を とり，明らかに，長い方の染色体以約 7 㑬，然 い方は約 4 堌のクロモメールより成つていて， 
後者は完全に前者と pairing ななっ，徒つて， 前者のもつ 3 㑬の余分のク口モメールは pairing 教なさない。

この二つの相同染色体の長さの差がいかにし て坐れたものであるか法不明であるが，少くと も転座によるものでないことは，他に型型示 守染色体が存在しない事加ら明らかである。他

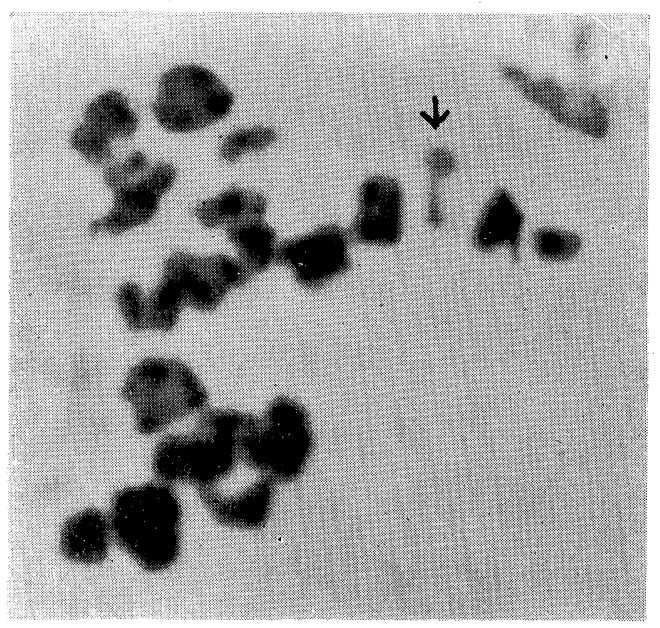

\section{図 1}

$\mathrm{V}$ 異型染色体の一対党示す（矢印） メ3500
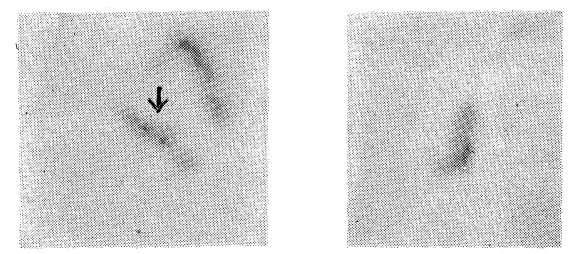

\section{図 2}

$\mathrm{V}$ 界型染色体学示寸. 分裂初期 Pachytene 期 に於けるこつの相同染色体の長さの異ることを 示寺. $\times 3500$

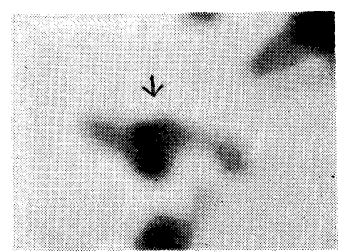

\section{図 3}

異型染色体の一対を示寸。〈4000 詳細《本交参照
の可能性，例 えば duplication p deletion に就いてはいまのところ，これを決定し得る根 挑はない。その起因が何であ万うと，とにかく この異型染色体が坐じたのは非常に古い時代で あり，既に日本の人口中に可成広く分布してい るものであることは。これらをるつ偑体が広い 地域にわたつて分散していることから明らかで

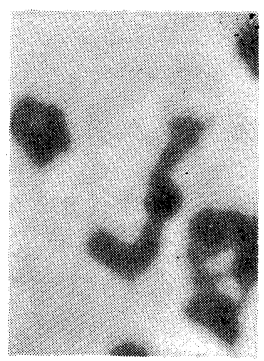

図5

一異型染色体対の中期の像 詳緗は本交参照 $\times 4000$

ある・日本人の国內に於ける移動は恐らく極可 て局限されたものであつたうう。従つて，この 異型染色体の分布の広さは，日本民族が日本へ 移動した時朁にそれら在集団內に所有していた ものであることを强く示していると考えられ る。この染色体対が今日の日本民族內に $゙$ の様 な分行をもつかは, 目下研究中であつて，その 結果走まつて，更にこの問題を論ずることろ致 したい。

この異型染色体をへテロにもつ，これら4人 の個体は少くとも外見に於いては何ら特異な型 質を示していない，人類学的計测及び血液学的 及び生化学的調查の結果をまつて, 果して, こ の染色体異常が遺伝学的に無表現のものか否か を決定したい，

この異型染色体をへテロにもつていないこと が確かな個体は，一飞れらは多数知られている が一明らかに長い方か或は短い方の染色体を木 モにもつ個体であるが，その心す机であるか は正確に決定し得ない。その理由はこれらの 染色体の長さの差が余りに小さ過ぎて，大きさ によつてそのいすれか在決定することは不可能 であるからである。これは分裂初期の染色体の 
クロモメールの数から決定し得ると考えられる が，実は技術的にこれも正確な結果を示すとは 限らないのである。従つていすれ机染色体がい かなる頻度を以つて日本人間に分布しているか も今晌不明である。然しこれは吾々の技術の発 展によつて解決され得ると思う。

筆者が発見した第二の異型染色体は，長崎県 島原市に原籍をもつ29才（材料入手当時）の 一男子に見出されたものである。この染色体付 は彼の睪丸の一部に局限されていない事と，原 爆の照射及び $\mathrm{X}$ 一線照射をうけた経験のない事 実よりここの染色体異常は両親より伝つたもの と見るのが至当であ万う。この異型染色体対は 図 3 に示す例から明らかな如く，形態の異る相 同染色体より成つている。一つは棒状であり,
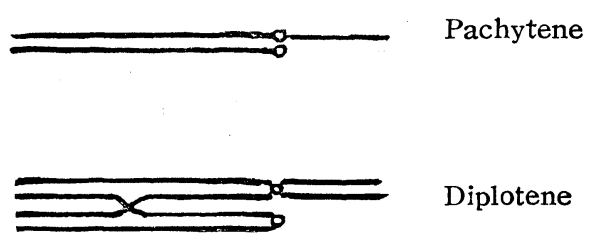

Diplotene

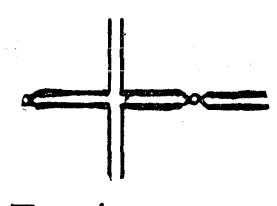

\section{Metaphase}

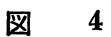

図 3 に示す異型染色体対の初期上り中期 に到る行動と形態の変化を示す。

他は J字型である。そして, 棒状の染色体は J 状染色体の長腕と相同であつて中期に於いてキ アズマによつて結ばれている。図4はこの染色 体対の初期より中期に至る变化を模式的に現し たものである。この模式図中の初期の像は実際 に観察されており，興味の染い点はJ字状染 色体の短腕即ち, pairing の起らない部分が spiral 状を呈し他の部分に比べて，その分裂時 過程の進行が可成おくれていることである。こ れは一種の negative heteropyenosis であつ $\tau$, この余分の部分が遺伝的に不活性な異質染 色質の特性を具えていること在示守と接えられ
る.

この染色体対の異型に就いても，その起因は 不明であるが，転座によるものでないことは明 らかである。恐らく众失によつて，短腕が失わ れたものであろうが，かような大きな部分の渻 失が何ら大きな遺伝的父陷を現していない事実 は恐らく，この失われた部分が遺伝的に不活性 な為であると考えられる。

この異型染色体钨が見出された男は，外見何 ら他の男と異るところはない。但し，人類学的 計測や血液学的及び生化学的調查怡完成してい ないのでこの異常がへテ口の状態で完全に無 表現であるか否かは断定し得ない。彼は未婚で あるので生殖力に就いては不明である。但しこ ろに附加したいことは彼には5人の兄弟があ り，近親者中にも生殖力或は体型に大きな異常 は認められない事である。

筆者が分析した他の男子は今日まですべてこ の染色体対中の J 字型の方をホモに有するもの 許りであつた。従つて，棒状染色体がホモに存 在し得るか否かは明らかでない。若し，この両 者が日本人間に分布しているならば，棒状染色 体をホモにもつ個体は極めてまれであ万う。そ してその分布る西九州の局限された地域に限ら れているのではなかろうか。この点に関しては 目下調查中であり，後日詳細を報告し得ると思 弓.

第三に挙げたい筫染色体対は東宗に居佳中 の一男子より得た材料に発見されたるのであ る.図 5 はこの染色体対の 1 例者示す。この図 に明らかな如く, 相同染色体の一つは $\mathrm{V}$ 字型 であるが，他は J字型である。後者の短䛷は前 者の一方の腕と相同であることが確認されたの で，分裂初期に於ける pairingは図6に示す 如きものであることが予期される。両腕に交丈 が起つた場合，及ざ一方の腕にのみ交又が起つ た場合には図 6 の右側に示すやうな二通りの中 期の像が予期されるが，両者共に実際に観察さ れた。

この買型染色体の起因も既に述べた二つの場 合と同様不明である。唯転座にょつて生じたも 


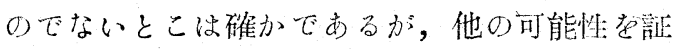
明守当根拪法見当らない。

この筫型染色休老己つ罗は外見何ら他の罗于 と異るところはない人類学的計测, 血液学的

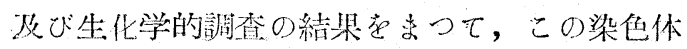
異賞が遗伝的表現を有与るか肴汃を明らかにし t6.

今日までに分析起終つた材料中，こ0異梨染
民族特に人類学的に近緗の珙民族中に於汁る分 布虫々の民族の分化や移動の労明に最も信賴し 得る根挑老与觉るものと思う。

人類の染色体に関して虫他に論ずべき問题が 多々あるか，それらに就いては他の機会に詳し くふれたいと思う・

\section{IV 要}

約

日本人助子の等丸中の第一成熱分裂の中期の

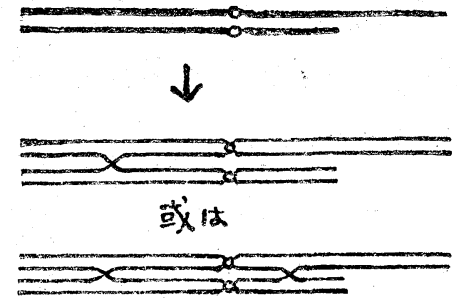

図 6

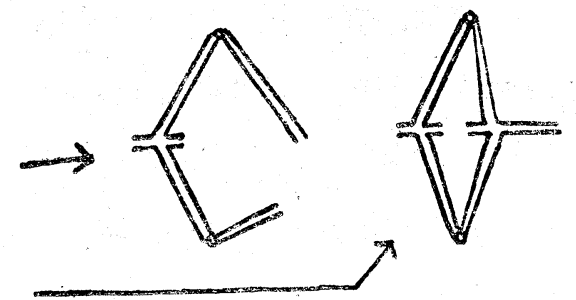

图 5 に示す異型染色体対の初期与り凹期に到る過程觉亦与。 キアズマのでき方の相異によつて二種の型体炎もつ丩期の像 が予期されること学示す。

色体を見出し得たものは上筑の 1 例のみであ る. 徒つて，これらの染色休の分有の頻度は全 く不明である。今後の研究によつてこの点老明 らかにしたい。

動物の一つの種の中に種々の買型染色体が発 見される典型的なものは Drosophila やOrthoptera の如き昆出である. Dobzhansky や White の研究によつて,これらの場合に於ける 異型染色体の進化的意義が明らかにされつ了市 る・人間の場合に於いては, 明膫な異型染色休 が報㪇されるの烛，篗者の揚合が最初である が，上記の三つの買型染色体中の第一のもの出 明らかに人類学的意義をもつものと思れ，かよ うな染他休の民族中に於ける分枋状態, 更に他
染他体を多数の材料によつて観然した結果， 3

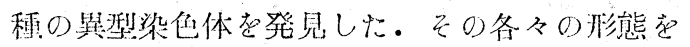

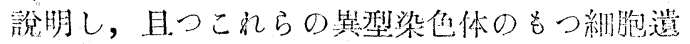
伀学的及び人颣学的意義に就いて㯴明した。

本論交は昭和 29 年 12 月 24 日に開催された東京 形態学談話会で述べた內容つ主要点をるとめたもの でめつて，既汇一距の英交諭文として印刷中の「日 本民族つ細胞遺伝学的研究」中の三編と汪が內容を 等しくし，こ〉に揭載する写真等ても重複している ものがある。

本硒究は $\mathrm{ABCC}$ と順天堂大:学の支持汇よつて行 われたものであつて, 算者恃, 本大学学長有山登㙛 士, 解剖学敉㥅椿宏治博士，東京大学医学部解剖学

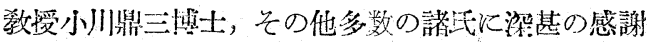
を挥げるものである.

\section{Summary}

A large number of the first metaphase figures in a number of testis spzcimens obtained from the Japanese malss in Japan were studied.

The results of our analyses indicate the existence of three different typ:s of hetromorphic paires of chromosomes in some of the specimens.

These were described in details and cytogenetic as well as the anthropological significance of these chromosomes is discussad briefly.

Department of Anatomy, Faculty of Medicine, Juntendo University. 